\title{
Infiltration Rates: Three Soils with Three Grazing Levels in Northeastern Colorado
}

\section{FRANK RAUZI AND FREEMAN M. SMITH}

Highlight: The influence of soil type, grazing level, and vegetation on infiltration rates were evaluated at the Central Plains Experimental Range near Nunn, Colorado. Total plant material was significantly correlated with infiltration rates on two of the three soil types tested. Heavy grazing significantly decreased infiltration rates on two of the soil types. Grazing influences did not reduce infiltration rates until after 20 minutes of simulated rainfall.

Physical properties of the soil mass and physical conditions of the soil surface control the infiltration process. In terms of the properties of the soil mass, Allis and Kuhlman (1962) found that runoff from native rangelands in South Dakota was three times greater from fine-textured soils than from medium-textured soils.

Hanks (1965) states that the physical condition of soil surface can indeed control the amount and rate of water entering the soil during a rain, but when the soil surface is well covered with plant material, surface scaling is quite small. However, for rangelands, it is surface conditions that are affected by grazing levels, both through removal of plant material and through compaction.

Physical changes in surface soil (i.e., compaction) resulting from grazing occur more slowly than changes in vegetation. Compaction often disappears after seasonal wetting and drying or freezing and thawing. Nevertheless, Rauzi et al. (1968) have shown that changes in both soil and vegetation can be evaluated by infiltration experiments.

Plant material, both standing crop and litter, have a pronounced effect on infiltration. In northern Utah, Meeuwig (1970) found that the weight of live plants and litter accounted for $73 \%$ of the variance in amount of water infiltrated by soil. At Mandan, N.D., Rauzi (1963) found that changes in weight of total plant material accounted for $88 \%$ of the variations in amount of water infiltrated on a silty upland range site. Dee et al, (1966) showed that the amount of water entering a Pullman silty clay loam was positively correlated with the amount of standing crop and litter on the soil.

The authors are supervisory soil scientist, U. S. Department of Agriculture at Laramie, Wyoming, and research assistant, Colorado State University at Fort Collins.

The paper is a contribution from the Northern Plains Branch, Soil and Water Conservation Research Division, Agricultural Research Service, U. S. Dep. Agr. and the U. S. IBP Grassland Biome Program, Colorado State University, Fort Collins, in cooperation with the Wyoming Agricultural Experiment Station. Research reported here was supported in part by National Science Foundation Grant GB-F824. Journal Article No. JA-500.

Manuscript received February 5, 1972.

\section{Study Area and Procedure}

This study was conducted at the Central Plains Experimental Range near Nunn, Colo. The purpose was to evaluate infiltration rates on three predominant soil types as affected by three grazing levels.

Average annual precipitation for the Central Plains Experimental Range is 12 inches. An average of 8.3 inches falls from May 1 through September 30, with a peak usually occurring in May or June.

The three major soils are Ascalon sandy loam, Shingle sandy loam, and Nunn loam. Ascalon sandy loam is a member of the fine loamy, mixed, mesic family of Aridic Argiustolls formed by fluvial outwash materials. The outwash materials consist primarily of granitic sediments (Franklin, 1969). These soils occupy the slopes.

Shingle sandy loam is a noncalcareous solum variant of the fine loamy, mixed mesic shallow family of Ustollic Camborthids formed on shale and siltstone outcrops of the Pierre sedimentary formation. Shingle sandy loam occupies the hills and knolls. These soils are shallow and moderately drained with a moderately light-textured surface and a moderately heavy-textured subsoil. The surface of these soils has ironstained shale and siltstone fragments.

Nunn loam is a noncalcareous variant, fine montmorillonitic mesic family of Aridic Argiustolls. The soils are deep, moderately well-drained with a medium texture, and a moderately textured subsoil. These soils occupy swales and lower portion of the slopes. Table 1 describes the experimental sites used in the study.

Vegetation is characterized by blue grama (Bouteloua gracilis) and buffalograss (Buchloe dactyloides), the dominant forage grasses. Red Threeawn (Aristida longiseta) is scattered throughout the lightly and moderately grazed pastures. Annual and perennial forbs are scattered throughout the pastures, but

Table 1. Soil, grazing level, and slope (\%) characteristics where infiltration experiments were conducted on the heavy, moderate, and light use pastures. Central Plains Experimental Range, 1970.

\begin{tabular}{clcl}
\hline Soil series & $\begin{array}{c}\text { Grazing } \\
\text { level }\end{array}$ & $\begin{array}{c}\text { Slope of } \\
\text { the site }\end{array}$ & $\begin{array}{c}\text { Slope } \\
\text { exposure }\end{array}$ \\
\hline Ascalon sandy loam & Heavy & $1-2$ & Southwest \\
(slopes) & Moderate & $1-2$ & East \\
& Light & $1-2$ & North \\
Shingle sandy loam & Heavy & $2-3$ & South \\
(knolls) & Moderate & $5-6$ & South \\
& Light & $5-6$ & North \\
Nunn loam & Heavy & $0-1$ & North \\
Swales & Moderate & $0-1$ & East \\
& Light & $0-1$ & East \\
\hline
\end{tabular}


are considered a minor part of the overall composition of the vegetation. Numerous annual forbs may become conspicuous in wet years.

Cattle stocking rates have averaged 4.14, 3.13, and 1.79 acres per yearling heifer per month for the lightly, moderately, and heavily grazed pastures, respectively. Vegetation changes obtained from differentially grazed pastures have been reported by Klipple and Costello (1960) and Bement (1968, 1969). Grazing for 23 years at the different stocking rates given above has not affected the species' frequency to a great extent, but heavy grazing has reduced herbage yields (Hyder et al., 1966).

Infiltration studies were conducted in June, 1970, on pastures grazed lightly, moderately, and heavily since 1940. Simulated rainfall was applied with a mobile infiltrometer (Rauzi et al., 1968) to a circular area of approximately $13 \mathrm{ft}^{2}$. The test plot was $2 \mathrm{ft}$ sq and located in the center of the circular area receiving the simulated rainfall. Simulated rainfall was applied to the test plots for $1 \mathrm{hr}$. The simulated rain rate was constant for each plot, but varied between 2.5 and 3.5 inches/hr among all plots.

Infiltration rates were measured as the difference between application rate and measured runoff rates. Runoff was measured volumetrically for each $5 \mathrm{~min}$ interval during the 1-hr test. Runoff rates were calculated by dividing the volume by the time increment.

Three tests were made on each soil type for each grazing level for a total of 27 test plots. All standing vegetation (standing crop) including growth of the previous year was clipped at ground level a few days after simulated rainfall was applied. All litter on test plots was also collected. The standing crop was separated by species and, together with the litter, was oven-dried and weighed. Yield values in pounds per acre for standing crop, litter, and total plant material (standing crop + litter) were calculated for each plot.

Data were analyzed by analysis of variance and simple correlations. Difference among means was tested for significance by Duncan's Multiple Range Test at the 5\% probability level.

\section{Results and Discussion}

At the time of the infiltration experiments, the soils were uniformly dry because precipitation was considerably below the long-time average. Precipitation from January 1 through June 30 was only 4.7 inches. The lack of May-June precipitation was reflected in the limited growth made by the native species.

Infiltration rates, standing crop, litter, and total plant material varied with the soil type and grazing level. The results obtained from the three grazing levels on three soils will be discussed separately by soil type.

\section{Ascalon Sandy Loam Site}

Blue grama and buffalograss were the dominant species (Fig. 1). Scattered plants of red threeawn were present on the lightly and moderately grazed pastures. Annual and perennial forbs were present on all grazing treatments. Sun sedge (Carex heliophila) was found scattered throughout the composition. Average weights of standing crop, litter, and total plant material on test plots are shown in Table 2. Blue grama and buffalograss accounted for nearly all herbage on the heavily grazed pasture, whereas they made up slightly over $50 \%$ of the total herbage on the lightly and moderately grazed pastures.

Because of variations in amount of standing vegetation on

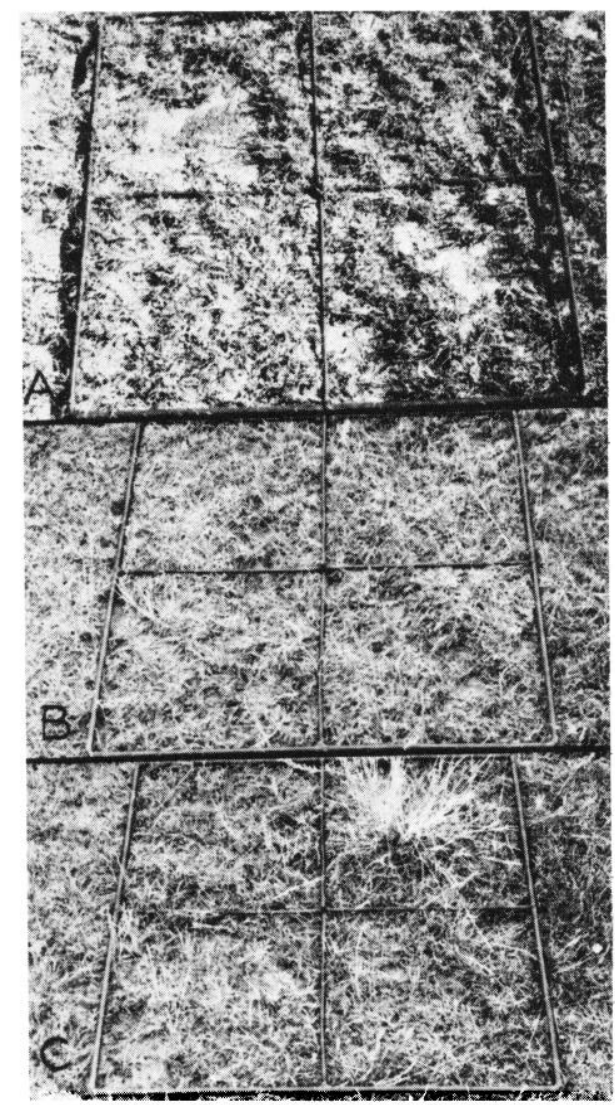

Fig. 1. Vegetative cover on the pastures on Ascalon fine sandy loam grazed: $A$-heavily, $B$-moderately, and $C$-lightly since 1940 .

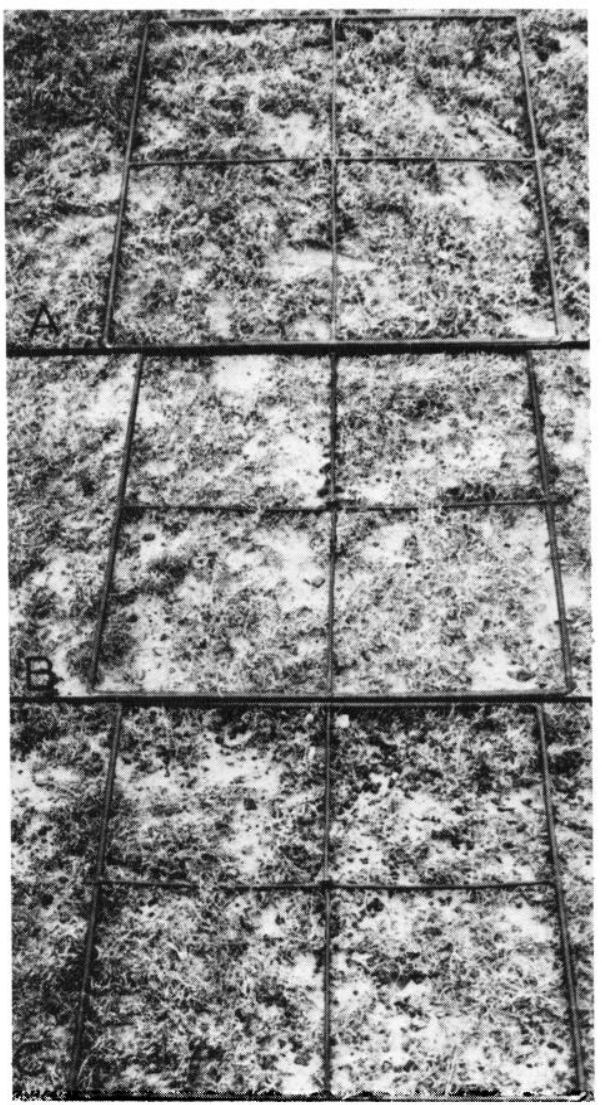

Fig. 3. Vegetative cover on the pastures on the Shingle sandy loam grazed: A-heavily, Bmoderately, and C-lightly since 1940.

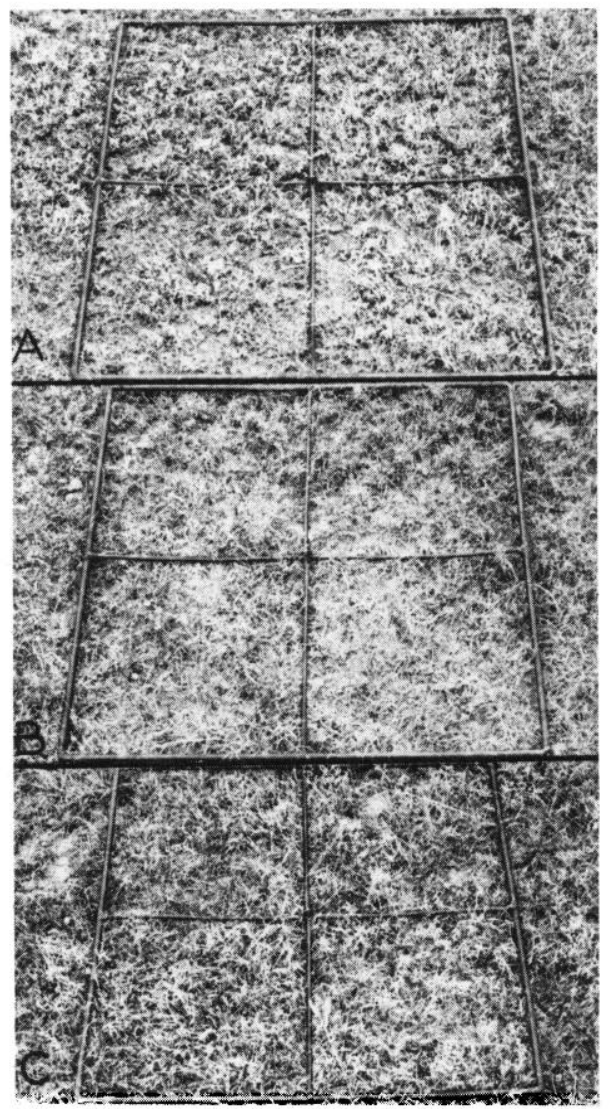

Fig. 4. Vegetative cover on the pastures on the Nunn loam grazed: $A$-heavily, $B$-moderately, and $C$-lightly since 1940 
Table 2. Weights (lb/acre) of standing crop, litter, and total plant material/acre and percent of shortgrasses making up the total herbage on three soils and three levels of grazing. Central Plains Experimental Range, 1970.

\begin{tabular}{llcccc}
\hline \hline Soil type & $\begin{array}{c}\text { Grazing } \\
\text { level }\end{array}$ & $\begin{array}{c}\text { Standing } \\
\text { crop }\end{array}$ & Litter & $\begin{array}{c}\text { Total } \\
\text { plant } \\
\text { material }\end{array}$ & $\begin{array}{c}\text { Percent } \\
\text { shortgrasses }\end{array}$ \\
\hline $\begin{array}{l}\text { Ascalon sandy } \\
\text { loam }\end{array}$ & Heavy & $482^{\mathrm{a}}$ & $339^{\mathrm{de}}$ & $821^{\mathrm{e}}$ & 97.5 \\
& $\begin{array}{l}\text { Moderate } \\
926^{\mathrm{a}}\end{array}$ & $\begin{array}{c}1062^{\mathrm{a}} \\
1988^{\mathrm{a}}\end{array}$ & 57.2 \\
Shingle sandy & Light & $1015^{\mathrm{a}}$ & $448^{\mathrm{d}}$ & $1463^{\mathrm{c}}$ & 55.8 \\
\multicolumn{1}{c}{ loam } & Heavy & $622^{\mathrm{a}}$ & $420^{\mathrm{d}}$ & $1042^{\mathrm{d}}$ & 88.4 \\
& Moderate & $346^{\mathrm{a}}$ & $252^{\mathrm{e}}$ & $598^{\mathrm{f}}$ & 90.3 \\
& Light & $607^{\mathrm{a}}$ & $97^{\mathrm{f}}$ & $704^{\mathrm{ef}}$ & 90.7 \\
& & & & & \\
Nunn loam & Heavy & $801^{\mathrm{a}}$ & $277^{\mathrm{e}}$ & $1078^{\mathrm{d}}$ & 87.9 \\
& Moderate & $714^{\mathrm{a}}$ & $864^{\mathrm{b}}$ & $1578^{\mathrm{bc}}$ & 84.6 \\
& Light & $1088^{\mathrm{a}}$ & $697^{\mathrm{c}}$ & $1785^{\mathrm{ab}}$ & 80.1 \\
\hline
\end{tabular}

$1_{\text {Means within columns followed by the same letter do not differ }}$ significantly at the 5\% level of significance according to Duncan's multiple range test.

the test plots, there were no significant differences among the three grazing levels for the three soil types (Table 2). There were significant differences in amounts of litter and total plant materid antung treatments and soils.

Infiltration rates after the first 15 -min period were significantly higher for the lightly and moderately grazed pastures than for the heavily grazed pasture (Fig. 2). During the first 15 min the infiltration rate for the lightly and moderately grazed pastures was 2.20 and 2.32 inches/hr, respectively, which accounted for $30 \%$ of the total water infiltrated during the 1-hr test. Infiltration rate during the first $15 \mathrm{~min}$ for the heavily grazed pasture was 1.88 inches/hr and accounted for $44 \%$ of the total water infiltrated during the 1 -hr test.

Infiltration rates for lightly and moderately grazed pastures were significantly greater $(\mathrm{P}>0.05)$ than for the heavily grazed pasture.

Infiltration rates for lightly and moderately grazed pastures began to increase slightly, whereas that for the heavily grazed pasture continued to decrease after $25 \mathrm{~min}$ of simulated rainfall (Fig. 2). Rhoades et al. (1964) reported a similar increase in infiltration rates. They suggested that perhaps during the early part of infiltration, some degree of hydrophobic behavior was occurring and that as wetting gradually occurred, infiltration rates increased.

We have no completely acceptable explanation, but it is most likely that the increase in infiltration rates is due to border effects. Briefly, it is known that infiltration is truly a three dimensional process. However, for the early part of the experiments, borders of the plot essentially confined infiltration to the vertical direction. Once the wetted front penetrated deeper than the plot borders, infiltration could have proceeded in all directions at a total rate greater than in the vertical only. Further experiments must be carried out to arrive at a more satisfactory accounting for our observations.

Simple correlation values between infiltration rates for each 5 -min period of the 1-hr test and total plant material were determined. All 5-min periods during the 1-hr test except the first two showed a correlation $(P>0.05)$ between infiltration rates and total plant material. The 45 -min period showed a correlation $(P>0.01)$ between infiltration rate and total plant material. Except for the 5-, 10-, and 45-min periods, 53\% to $63 \%$ of the variation in rate of infiltration was accounted for

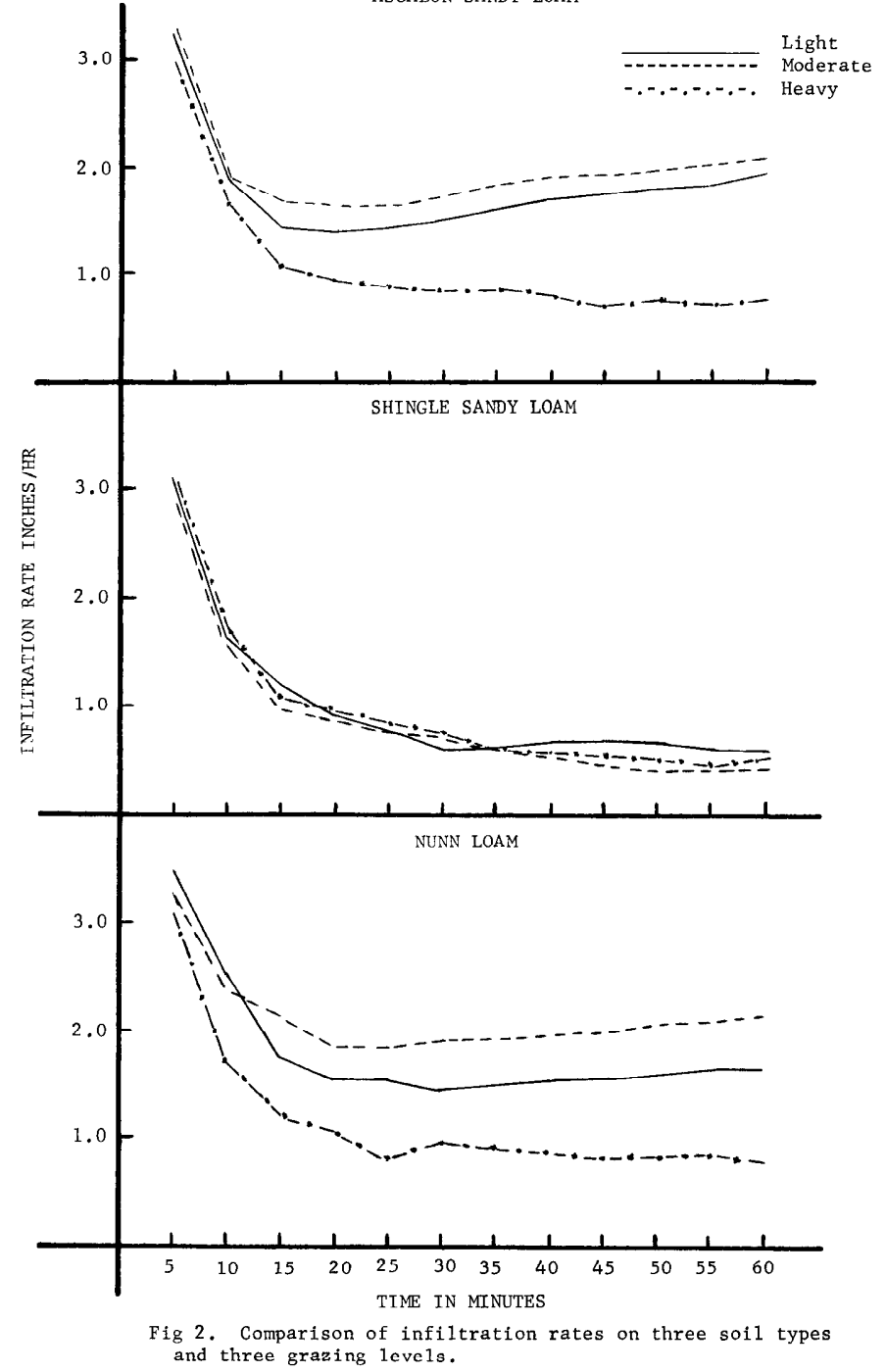

Fig. 2. Comparison of infiltration rates on three soil types and three grazing levels.

by the amount of total plant material.

The infiltration rate during the first 30 -min period of the 1 hr test was not significantly correlated with total plant material, whereas the infiltration rate during the second 30-min period and for the hr was correlated with total plant matcrial (Tablc 3).

\section{Shingle Sandy Loam Site}

Blue grama and buffalograss accounted for $90 \%$ of total herbage at all levels of grazing (Table 2). There were significant differences in amount of litter and total plant material between grazing levels (Fig. 3).

There were no significant differences in infiltration rates between the grazing levels for any time interval, indicating that

Table 3. Simple correlation values of total plant material and infiltration rates in inches/hr for the first and second $30-\mathrm{min}$ period and $1-\mathrm{hr}$ period for the Ascalon and Shingle sandy loams and Nunn loam sites.

\begin{tabular}{lccc}
\hline \hline Minute intervals & $\begin{array}{c}\text { Ascalon } \\
\text { sandy loam }\end{array}$ & $\begin{array}{c}\text { Shingle } \\
\text { sandy loam }\end{array}$ & Nunn loam \\
\hline First 30-min & .664 & -.088 & $.749^{*}$ \\
Second 30-min & $.788^{*}$ & -.203 & $.706^{*}$ \\
Total 60-min & $.799^{*}$ & -.146 & $.724^{*}$ \\
\hline
\end{tabular}

${ }^{*}$ Significant at $5 \%$ level. 
soil characteristics were more important than level of grazing (Fig. 2).

There was a high percentage of bare ground on plots as may be seen in Fig. 3. The beating action of the raindrops on the bare soil resulted in puddling and sealing of the soil surface. Between $48 \%$ and $51 \%$ of the total water infiltrated (light 1.01 inches, moderate 0.90 inch, and heavy 0.97 inch) during the 1 -hr test occurred during the first $15 \mathrm{~min}$. These results indicate that runoff would be rapidly generated from a storm with high rainfall rates.

Infiltration rates for each 5-min period of the 1-hr test and total plant material were not significantly correlated during any of the 5-min periods or the 1-hr period. In all but two of the 5-min periods, the correlations were negative. Infiltration rates and total plant material were not significantly correlated during the first and second 30 -min period or the 1 -hr period (Table 3).

\section{Nunn Loam Site}

Blue grama and buffalograss accounted for $80 \%$ to $85 \%$ of total herbage (Table 2). Sun sedge, 6-weeks-fescue (Festuca octoflora), and a scattering of annual and perennial forbs made up the rest of the composition. There were significant differences in amount of litter and total plant material between grazing levels. Total plant material was significantly greater on pastures lightly and moderately grazed than on heavily grazed pastures (Fig. 4 and Table 2).

During the first 15 min the infiltration rate for lightly and moderately grazed pastures was 2.56 and 2.72 inches/hr, respectively, and accounted for $30 \%$ of the total water infiltrated during the 1-hr test. The infiltration rate during the first $15 \mathrm{~min}$ for the heavily grazed pastures was 2.04 inches $/ \mathrm{hr}$ and accounted for $44 \%$ of the total water infiltrated during the 1 -hr test. Infiltration rates for the first and second 30 -min periods and the 1-hr period were significantly higher for lightly and moderately grazed pastures than for heavily grazed pastures. There was no significant difference in infiltration rates between lightly and moderately grazed pastures.

Simple correlations between infiltration rates for each 5 -min period of the 1-hr test and total plant material showed no significant correlation $(\mathrm{P}>0.05)$ until the 25 -min period of the test. After $30 \mathrm{~min}$ of the 1-hr test, infiltration rates and total plant material were significantly correlated $(\mathrm{P}>0.05)$.

Significant correlations during the 5 -min period showed that from $46 \%$ to $60 \%$ of the variation in infiltration rate was accounted for by total plant material. Soil structure in the first horizon was nut-like and conducive to water movement. This was an important factor for this site.

Infiltration rates for the first and second 30 -min periods and the 60 -min period were significantly $(\mathrm{P}>0.05)$ correlated with total plant material (Table 3).

\section{Conclusions}

For Ascalon sandy loam, infiltration rates after $15 \mathrm{~min}$ for light and moderate grazing levels were significantly higher than for the heavy grazing level, but not different from each other. Similarly, for Nunn loam soil, infiltration rates for the first and second $30-\mathrm{min}$ periods and for the total $60-\mathrm{min}$ period for light and moderate grazing levels were significantly higher than for the heavy grazing level, but again, were not different from each other. Finally, for Shingle sandy loam, there was no difference in infiltration rates among light, moderate, and heavy grazing levels.

If the significance of soils, grazing, and soils $x$ grazing is inspected in terms of infiltration rates for given time intervals, an interesting pattern emerges. During the first $10 \mathrm{~min}$ of the infiltration process, only the effect of soils is significant. After $15 \mathrm{~min}$, grazing influences are detectable; after $20 \mathrm{~min}$, soil and grazing effects are equally important. By $30 \mathrm{~min}$, interaction appears important. This interaction most probably arises from the Shingle sandy loam, for which there was no significant difference in infiltration rates for any time period for any grazing level.

Infiltration data obtained from this study indicate that moderate grazing of vegetation on the Ascalon sandy loam and Nunn loam soils would be recommended. Even though differences in infiltration rates were not significant between grazing levels on Shingle sandy loam soils, moderate grazing would be recommended.

\section{Literature Cited}

Allis, John A., and Armine R. Kuhlman. 1962. Runoff and sediment yields on rangeland watersheds. J. Soil and Water Conserv. $17: 68-71$.

Bement, R. E. 1968. Plains pricklypear: Relation to grazing intensity and blue grama yields on the central plains. J. Range Manage. 21:83-86.

Bement, R. E. 1969. A stocking rate guide for beef production on blue grama range. J. Range Manage. 22:83-86.

Brustkern, R. L. 1970. An analytical treatment of two phase flow during infiltration. Ph.D. Diss. Colorado State Univ., Fort Collins.

Dee, Richard F., Thadis W. Box, and Ed Robertson. 1966. Influence of grass vegetation on watcr intake of a Pullman silty clay loam. J. Range Manage. 19:77-79.

Franklin, William T. 1969. Mineralogy of representative soils at the Pawnee site. U. S. IBP Grassland Biome Tech. Rcp. No. 30. Colorado State Univ., Fort Collins p. 1-12

Hanks, R. J. 1965. Estimating infiltration from soil moisture properties. J. Soil and Water Conserv. 20:49-51.

Hyder, D. N., R. E. Bement, E. E. Remmenger, and C. Terwilliger, Jr. 1966. Vegetation-soils and vegetation-grazing relations from frequency data. J. Range Manage. 19:11-17.

Klipple, G. E., and David F. Costello. 1960. Vegetation and cattle responses to different intensities of grazing shortgrass ranges on the Central Great Plains. U. S. Dep. Agr. Tech. Bull. 1216. 82 p.

Meeuwig, Richard 0. 1970. Infiltration and soil erosion as influenced by vegetation and soil in northern Utah. J. Range Manage. 23:185-188.

Rauzi, Frank. 1963. Water intake and plant composition as affected by differential grazing on rangeland. J. Soil and Water Conserv. 18:114-116.

Rauzi, Frank, C. L. Fly, and E. J. Dyksterhuis. 1968. Water intake on midcontinental rangelands as influenced by soil and plant cover. $U$. S. Dep. Agr. Tech. Bull. 1390. 58 p.

Rhoades, Edd D., Lowell F. Locke, Howard M. Taylor, and E. H. McIlvain. 1964. Water intake on a sandy range as affected by 20 years of differential cattle stocking rates. J. Range Manage. 17:185-190.

Sharp, A. L., J. J. Bond, J. W. Neuberger, A. R. Kuhlman, and J. K. Lewis. 1964. Runoff as affected by intensity of grazing on rangeland. J. Soil and Water Conserv. 19:103-106. 